\title{
Tingkat Kecemasan Perawat ICU Dimasa Pandemi COVID-19 : Literature Review
}

\author{
Sisca Amelia ${ }^{1 *}$, Benny Arief Sulistyanto ${ }^{2}$ \\ ${ }_{1,2}$ Prodi Sarjana Keperawatan, Universitas Muhammadiyah Pekajangan Pekalongan, Indonesia \\ *email:sisca096@gmail.com
}

\begin{abstract}
At the beginning of 2020, the whole world was shocked by the emergence of a new irus, namely the coronavirus (SARS-CoV-2). The high rate of transmission of COVID-19 has resulted in a psychological impact on ICU nurses, one of which is anxiety. They are faced with mental health risks such as fear or anxiety if they carry a virus that endangers family or friends and are afraid of being infected. To identify the anxiety of ICU nurses during the Covid-19 pandemic. It is a literature review. The process was by searching articles in two databases; PubMed and ScienceDirect. The searching used Critical Care Nurse, COVID-19 pandemic and anxiety as the keywords. There were 5 articles in inclusive and exclusive criteria and meet the critical review with the JBI (The Joanna Briggs Institute) instrument. The results stated from the total samples 1.353 , there was $45,8 \%$ of ICU nurse ere in anxiety during COVID-19 pandemic. This pandemic has an impact on nurses' mental health, especially for ICU nurses. During the current COVID-19 pandemic, it is very important to pay attention to the mental health condition of nurses, especially ICU nurses. It suggested for them to see a psychiatrist or psychologist to recognizze their mental conditons so as to reduce anxiety levels.
\end{abstract}

Keywords : Anxiety; COVID-19 Pandemic; ICU Nurse

\begin{abstract}
Abstrak
Pada awal tahun 2020, diseluruh dunia digemparkan dengan munculnya virus baru yaitu coronavirus (SARS-CoV-2). Tingginya tingkat penularan COVID-19 ini mengakibatkan dampak psikologis pada perawat ICU salah satunya adalah kecemasan. Perawat yang bekerja di ICU di saat pandemi ini dihadapkan dengan resiko kesehatan mental mereka seperti takut atau cemas membawa virus dan membahayakan keluarga atau teman sejawat serta takut terinfeksi. Untuk mengidentifikasi kecemasan perawat ICU dimasa pandemi Covid-19. Metode penelitian yang digunakan adalah literature review dengan mencari artikel dari dua data base yaitu PubMed dan ScienceDirect. Pencarian dilakukan dengan menggunakan kata kunci "Critical Care Nurse" AND "COVID-19 Pandemic" AND "anxiety". Terdapat lima artikel yang memenuhi kriteria inklusi dan ekslusi penelitian, serta memenuhi telaah kritis dengan instrumen JBI (The Joanna Briggs Institute). Hasil dari penelitian ini menunjukan bahwa dari beberapa perawat dengan total sampel 1.353 terdapat $45,8 \%$ perawat ICU mengalami kecemasan selama pandemi COVID-19. Pandemi COVID - 19 ini memberikan dampak kesehatan mental perawat khususnya pada perawat ICU. Dimasa pandemi COVID-19 seperti saat ini, pentingnya memperhatikan kondisi kesehatan mental perawat khususnya perawat ICU. Seperti bertemu dengan psikater/ psikolog untuk mengenali kondisi mental perawat khususnya dengan gejala kecemasan dapat mengurangi tingkat kecemasan yang terjadi.
\end{abstract}

Kata kunci : Kecemasan; Pandemi COVID-19; Perawat ICU

\section{Pendahuluan}

Pada awal tahun 2020, diseluruh dunia digemparkan dengan munculnya virus baru yaitu coronavirus yang disebut dengan SARS-CoV-2. Penyakit ini disebabkan oleh virus yang disebut dengan Coronavirus disease2019 (COVID-19). Penemuan virus ini ditemukan di Kota Wuhan, Tiongkok pada bulan Desember 2019 [39]. Pada tanggal 


\section{Prosiding Seminar Nasional Kesehatan 2021 Lembaga Penelitian dan Pengabdian Masyarakat Universitas Muhammadiyah Pekajangan Pekalongan}

11 Juli 2021, World Health Organization (WHO) menyebutkan jumlah penderita yang terkonfrimasi 185,291,530 dan jumlah kematian yang terkonfirmasi 4,010,834 [35]. Pada tanggal 11 Juli 2021, Kementerian Kesehatan Republik Indonesia menyebutkan penyebaran kasus yang terkonfirmasi COVID-19 di Indonesia sebanyak 2,527,203 kasus, penyebaran kasus meninggal terkait COVID-19 sebanyak 66,464 dan penyebaran kasus sembuh terkait COVID-19 sebanyak 2,084,724 [14].

Studi pengendalian dan pencegahan penyakit China (CDC) menyebutkan petugas kesehatan yang terpapar diawal bulan Februari sebanyak 3,8\% dan kematian keseluruhan terkait COVID-19 sebanyak 2,3\% [15]. Di Italia perawat yang terpapar COVID-19 sebanyak $10 \%$ dan 3\% perawat meninggal dunia karena COVID-19 [21]. Italia merupakan negara yang pertama terkena pandemi COVID-19 dan harus menghadapi perawatan kesehatan darurat terkait pandemi tersebut [16]. Tingginya tingkat penularan COVID-19 ini mengakibatkan dampak psikologis pada perawat salah satunya adalah kecemasan. [21] .

Prevalensi kecemasan perawat yang merawat pasien COVID- 19 di ICU sebesar 17,6\% selama pandemi COVID-19 [17]. Begitu pula dengan perawat yang menangani pasien COVID-19 mengalami dampak psikologis dari adanya pandemi ini. Perawat juga menjadi garda didepan yang mencoba menyelamatkan nyawa pasien dan memainkan peranan penting dalam mengendalikan pandemi ini [4]. Oleh karena itu, perawat harus melakukan upaya pencegahan untuk mengurangi kecemasan terkait COVID19.

\section{Metode}

Desain penelitian ini menggunakan desain literature review terhadap 5 artikel dari database online PubMed dan ScienceDirect dengan menggunakan kata kunci Bahasa Inggris "Critical Care Nurse" AND "COVID-19 Pandemic" AND "Anxiety" yang mengacu pada PCC. Penelitian ini menggunakan teknik analisa deskriptif, yaitu analisa yang berfungsi untuk menggambarkan suatu variabel. Instrument yang digunakan adalah Cheklist for analytical cross sectional studies kuesioner terlampir dari JBI (The Joanna Briggs Institute) critical appraisal tool for use in JBIsystematic riviews. Artikel dibatasi menggunakan kriteria inklusi dan ekslusidan yang diterbitkan pada tahun 2019-2021. Lima artikel yang digunakan pada penelitian ini ialah Hide Heesakkers, et al., (2021), Sarah Crowea et al., (2020), Elie Azoulay et al., (2021), Murat Saricam, (2020) dan Marialaura Di Tella et al., (2021). waktu penelitian ini dimulai dari bulan Februari sampai bulan Juli.

\section{Hasil dan Pembahasan}

Hasil

Distribusi frekuensi karakteristik responden dari lima artikel diperoleh populasi / sampel dengan total 1.353. Dari tiga artikel Hide Hesakkers et al.,(2021), Sarah Crowea et al.,(2020) dan Marialaura Di Tella et al.,(2021) dihasilkan mayoritas responden yang bekerja di ICU berjenis kelamin perempuan sebanyak $76 \%$ dan lakilaki 24\%. Dari 3 artikel Hide Hesakkers et al.,(2021), Sarah Crowea et al.,(2020) dan Marialaura Di Tella et al.,(2021) usia perawat yang bekerja di ICU memiliki rata- rata 37 - 45 tahun. Dan dari 2 artikel Hide Hesakkers et al.,(2021) dan Sarah Crowea et 


\section{Prosiding Seminar Nasional Kesehatan Lembaga Penelitian dan Pengabdian Masyarakat Universitas Muhammadiyah Pekajangan Pekalongan

al.,(2020) perawat yang memiliki pengalaman kerja di ICU rata-rata 6-16 tahun. Adapun rincian karakteristik responden tersebut, dapatdilihatpada tabel 1 dibawah ini.

Tabel 3.1 Distribusi Responden Berdasarkan Usia, Jenis Kelamin dan Pengalaman Kerja Di ICU $(\mathrm{N}=1.353)$

\begin{tabular}{|c|c|c|c|c|}
\hline $\begin{array}{l}\text { Karakteristik } \\
\text { Reponden }\end{array}$ & & $\begin{array}{l}\text { Nama } \\
\text { Peneliti }\end{array}$ & & \\
\hline & $\begin{array}{l}\text { Hide } \\
\text { Heesakker, } \\
\text { et.al. 2021 } \\
(\mathbf{N}=\mathbf{7 2 6})\end{array}$ & $\begin{array}{l}\text { Sarah } \\
\text { Crowea, } \\
\text { et.al. 2020 } \\
(\mathrm{N}=109)\end{array}$ & $\begin{array}{l}\text { Marialaura } \\
\text { Di Tella, et } \\
\text { al } 2021 \\
(\mathbf{N}=73)\end{array}$ & Total \\
\hline \multicolumn{5}{|l|}{ Jenis kelamin } \\
\hline Perempuan & $73,8 \%$ & $98,9 \%$ & $75,3 \%$ & $76 \%$ \\
\hline Laki - laki & $26,2 \%$ & $10,1 \%$ & $24,7 \%$ & $24 \%$ \\
\hline \multicolumn{5}{|l|}{ Usia } \\
\hline Rata-rata & 45,0 tahun & 37,1 tahun & 44,3 tahun & \\
\hline Rentang & - & $24-64$ & - & \\
\hline Median & - & 36 & - & \\
\hline SD & 11,4 & - & 10,6 & \\
\hline \multicolumn{5}{|l|}{$\begin{array}{l}\text { Pengalaman } \\
\text { kerja di ICU }\end{array}$} \\
\hline Rata - rata & 16,2 tahun & 6,1 tahun & - & \\
\hline Rentang & - & $0,16-23$ & - & \\
\hline Median & - & 5 & - & \\
\hline SD & 11,3 & - & - & \\
\hline
\end{tabular}

Distribusi prevalensi kecemasan perawat ICU dari lima artikel dengan total populasi 1.353 responden, jumlah prevalensi kecemasan perawat ICU adalah 45,8\%. Prevalensi kecemasan yang paling rendah adalah 27\% Hide Hesakkers et al., (2021) dengan instrumen HADS, sedangkan yang paling tinggi adalah $100 \%$ Murat Saricam, (2020) dengan instrumen STAI. Adapun rincian prevalensi tersebut, dapat dilihat pada tabel 2 dibawah ini.

Tabel 3.2 Distribusi prevalensi kecemasan perawat ICU $(\mathrm{N}=1.353)$

\begin{tabular}{clllll}
\hline No & Artikel & Instrumen & $\mathbf{N}$ & Cemas & \% \\
\hline 1 & $\begin{array}{l}\text { Hidde Heesakkers, et.al } \\
(2021)\end{array}$ & HADS & 726 & 196 & $27 \%$ \\
\hline 2 & Sarah Crowea, et.al (2020) & DASS-21 & 109 & 73 & $67 \%$ \\
\hline 3 & Elie Azoulay, et.al (2021) & HADS & 412 & 264 & $64 \%$ \\
\hline 4 & Murat Saricam, (2020) & STAI & 33 & 33 & $100 \%$ \\
\hline 5 & $\begin{array}{l}\text { Marialaura Di Tella, et.al } \\
(2021)\end{array}$ & STAI & 73 & 55 & $75 \%$ \\
\hline$\quad$ Jumlah responden & & 1.353 & 621 & - \\
\hline & Rata- rata persentase & & & $45,8 \%$ \\
\hline
\end{tabular}

Distribusi tingkat kecemasan perawat ICU lima artikel yang dianalisis, hanya dua artikel yang mengkategorikan data tingkat kecemasan perawat ICU. Artikel Sarah Crowea et.al., (2020) dengan instrumen DASS-21 mengkategorikan tingkat kecemasan menjadi ringan, sedang, parah, sangat parah. Sedangkan Murat Saricam, (2020) dengan instrumen STAI hanya mengkategorikan kecemasan ringan dan tinggi. Oleh karena itu instrumen dan kategori tingkat kecemasan yang digunakan peneliti tersebut berbeda, maka analisis presentase tingkat kecemasan tidak dapat diakumulasi. Adapun tingkat kecemasan perawat dapat dilihat pada table 3 dibawah ini. 


\section{Prosiding Seminar Nasional Kesehatan Lembaga Penelitian dan Pengabdian Masyarakat Universitas Muhammadiyah Pekajangan Pekalongan}

Tabel 3.3 Distribusi tingkat kecemasan perawat ICU

\begin{tabular}{|c|c|c|c|c|}
\hline & & $\begin{array}{l}\text { Nama } \\
\text { Peneliti }\end{array}$ & & \\
\hline $\begin{array}{l}\text { Tingkat } \\
\text { kecemasan }\end{array}$ & $\begin{array}{l}\text { Sarah } \\
\text { Crowea, et.al } \\
2020 \\
(\mathrm{~N}=109)\end{array}$ & & $\begin{array}{l}\text { Murat } \\
\text { Saricam, } \\
2020 \\
(\mathbf{N}=33)\end{array}$ & \\
\hline & $\mathbf{N}$ & $\%$ & $\mathbf{N}$ & $\%$ \\
\hline \multicolumn{5}{|l|}{ Instrumen DASS-21 } \\
\hline Normal ( 0-7 poin) & 35 & $32,1 \%$ & - & - \\
\hline Ringan ( $8-9$ poin ) & 28 & $25,7 \%$ & - & - \\
\hline Sedang $(10-14$ poin $)$ & 16 & $14,7 \%$ & - & - \\
\hline Parah ( $10-14$ poin) & 6 & $5,5 \%$ & - & - \\
\hline $\begin{array}{l}\text { Sangat parah (lebih dari } 20 \\
\text { poin) }\end{array}$ & 23 & $21,1 \%$ & - & - \\
\hline Tidak menjawab & 1 & $0,9 \%$ & & \\
\hline \multicolumn{5}{|l|}{ Instrumen STAI } \\
\hline Rendah & - & - & 25 & $37,8 \%$ \\
\hline Tinggi & - & - & 8 & $14 \%$ \\
\hline
\end{tabular}

\section{Pembahasan}

\section{Karakteristik responden}

Berdasarkan dari hasil 3 artikel didapatkan rata- rata perawat yang bekerja di ICU dengan usia dewasa yaitu 37-45 tahun. Hal ini sejalan dengan penelitian yang telah dilakukan di tiga rumah sakit dan sembilan pelayanan kesehatan pada bulan April 2020 dengan mayoritas responden rata-rata berusia dewasa yang merupakan kelompok yang mempunyai kecemasan ringan, pada kelompok ini rata-rata sudah berkeluarga karenanya respon emosialnya bisa bercabang dan berubah-ubah sesuai dengan kondisi dan situasi yang ada [8].

Usia berhubungan dengan pengalaman, pengalaman berhubungan dengan pengetahuan, pemahaman dan pandangan terhadap suatu penyakit atau kejadian sehingga akan membentuk persepsi atau sikap. Kematangan dalam proses berfikir pada individu berusia dewasa lebih memungkinkan menggunakan mekanisme koping yang baik dibandingkan usia yang lebih muda. Dari hasil peneitian itu peneliti berasumsi bahwa semakin bertambahnya usia seseorang kecemasan akan berkurang dan maka akan semakin tinggi pula tingkat mekanisme koping terhadap suatu stressor [26].

\section{a. Karakteristik jenis kelamin}

Berdasarkan dari hasil 3 artikel didapatkan perawat yang bekerja di ICU bermayoritas dengan jenis kelamin perempuan sebanyak $76 \%$ dan laki- laki sebanyak 24\%. Gangguan kecemasan cenderung akan terjadi pada perempuan. Dikarenakan perubahan hormonal selama haid, hamil, menyusui, serta menopause dapat juga mempengaruhi perubahaan mood serta menyebabkan depresi dan meningkatkan rasa cemas [10].

Perempuan umumnya akan lebih cepat mengalami kecemasan dibandingkan dengan laki-laki. Hal ini dapat dilihat dari respon biologik yang berbeda yang diperlihatkan oleh laki-laki dan perempuan ketika dihadapkan dengan stressor [22]. Ada satu konsep yang berfokus pada perbedaan 


\section{Prosiding Seminar Nasional Kesehatan 2021 Lembaga Penelitian dan Pengabdian Masyarakat Universitas Muhammadiyah Pekajangan Pekalongan}

antara laki-laki dan perempuan yaitu corpus collosum (sekumpulan yang menggabungkan kedua belahan otak) pada perempuan corpus collosum lebih besar dari pada laki-laki. Hal ini menjelaskan mengapa perempuan bisa lebih peka dan sadar dibandingkan laki-laki dalam hal emosi mereka sendiri dan emosi orang lain. Perempuan lebih cenderung mudah terbawa perasaan serta emosi menghadapi berbagai kondisi yang sedang terjadi [13].

\section{b. Karekteristik pengalaman kerja}

Hasil dari 2 artikel yang dianalisa didapatkan bahwa perawat yang bekerja di ICU memiliki pengalaman kerja dengan rata-rata 6-16 tahun. Lama kerja dapat menggambarkan pengalaman seseorang dalam menguasai bidang tugasnya. Pada umumnya, perawat dengan pengalaman kerja yang banyak tidak memerlukan bimbingan dibandingkan dengan perawat yang pengalaman kerjanya sedikit. Semakin lama seseorang bekerja maka semakin berpengalaman kecakapan kerjanya dan semakin baik. Berkaitan dengan pengalaman kerja dan tingkat kecemasan perawat yaitu jika perawat sudah lama menggeluti pekerjaanya dan terbiasa dalam menyelesaikan tugasnya sehingga kecemasan yang dialami dalam bekerja akan menjadi lebih ringan atau berkurang [2].

Karena mereka dapat menemukan kesempatan untuk melakukan perbandingan antara penyakit umum yang sering dijumpai dengan penyakit pandemi COVID-19 [28]. Tingkat pengalaman kerja perawat yang bertugas dibangsal ICU RSUD Sawerigading kota Palopo memiliki pengaruh yang signifikan terhadap tingkat kecemasan dalam memberikan penanganan pada pasien dengan kondisi gawat darurat [2]. Dari hasil ini ditandai dari 2 artikel Sarah Crowea et, al (2020) dengan menggunakan instrumen DASS-21 dan Murat Saricam, (2021) dengan instrumen STAI. Dari dua artikel tersebut tingkat kecemasan lebih bermayoritas terjadi pada kecemasan ringan. Artinya, perawat yang bertugas sudah tidak terlalu cemas lagi dalam menangani pasien gawat darurat atau kritis, sebab perawat didominasi oleh perawat yang sudah berpengalaman kerja dan sudah lama bertugas.

\section{Prevalensi kecemasan perawat ICU}

Secara keseluruhan, hasil penelitian dari lima artikel dengan total 1.353 responden perawat yang bekerja di ICU terdapat 621 reponden yang cemas, $(45,8 \%)$ mengalami kecemasan terkait pandemi COVID-19. Prevalensi kecemasan pada perawat ICU sebanyak 17,6\% [17]. selama adanya pandemi COVID-19 ,perawat memiliki tanggung jawab yang lebih besar dibandingkan dengan sebelum adanya COVID-19. Hal tersebut meningkatkan kemungkinan terjadinya stressor yang lebih tinggi karena harus memberikan dukungan sosial secara langsung atau dukungan emosional untuk pasien sebagai pengganti keluarga pasien yang tidak diperbolehkan masuk rumah sakit karena masalah transmisi atau penularan. Keadaan darurat pandemi telah menentukan kondisi kerja yang penuh tekanan bagi tenaga kesehatan khususnya perawat ICU [20]. Namun, ketakutan atau kekhawatiran terinfeksi COVID-19 telah memainkan peranan paling relevan dalam 


\section{Prosiding Seminar Nasional Kesehatan 2021 \\ Lembaga Penelitian dan Pengabdian Masyarakat Universitas Muhammadiyah Pekajangan Pekalongan}

menentukan kecemasan ditempat kerja [16]. Kecemasan merupakan sebuah fenomena kognitif, dimana seseorang tersebut akan merasa terjadi sesuatu diluar kehendak dan tidak bisa diprediksi. Kecemasan akan diperoleh jika perawat mengganggap tidak sanggup menghadapinya karena meragukan kemampuannya sendiri. Peristiwa - peristiwa dari dalam dan diluar dapat memicu terjadinya kecemasan. Kecemasan yang dihadapi perawat akan sangat mempengaruhi kualitas pelayanan keperawatan yang diberikan kepada pasien [1].

\section{Tingkat kecemasan perawat ICU}

Tingkat kecemasan seseorang sangatlah bervariasi, dari kecemasan ringan, sedang, parah dan sangat parah atau panik. Hasil penelitian ini dari dua artikel menunjukan data tingkat kecemasan bermayoritas ringan. Kecemasan dengan mayoritas ringan, hal ini terjadi karena sebagian perawat yang sudah terpapar dengan adanya informasi mengenai COVID -19, penyebab COVID-19, tanda dan gejala serta penanganan COVID-19 menjadi lebih waspada dan berhati-hati saat hendak melakukan suatu kegiatan, seiring berjalannya waktu mindset perawat juga berubah sejak adanya pandemi dan banyak mengalami perubahan yang terjadi dan lebih kearah perubahan yang positif seperti selalu menjaga kesehatan diri sendiri, keluarga dan orang sekitarnya dengan cara tidak lupa cuci tangan, selalu memakai masker dan APD yang tepat sesuai tempat perawat bekerja. Lebih mempedulikan kesehatan diri sendiri, cemas akan resiko penularan penyakit terhadap keluarga, dan lebih berhati-hati melakukan kegiatan dengan orang orang baru. Pada penelitian ini didapatkan perawat ICU mengalami tingkat kecemasan dengan mayoritas kecemasan ringan, hal ini bisa terjadi karena pengaruh faktor kenyamanan dan situasi lingkungan yang bisa membuat perawat tidak cemas, biasanya pasien yang masuk ke ruangan ICU adalah pasien yang mengalami penurunan kesadaran dengan GCS rendah dimana biasanya semua kegiatan dilakukan dibantu oleh perawat. Selain itu, suasana ruangan yang tenang serta perawatan yang berulang yang sama dilakukan oleh perawat lebih memahami apa yang akan dilakukan di jam jam pemeriksaan selanjutnya, dan untuk ruangan ICU jumlah pasien juga tidak terlalu banyak seperti pada ruangan lainnya [27].

Pandemi COVID - 19 ini memberikan dampak pada tatanan sosial, kegiatan ekonomi, dan sistem kesehatan secara global. Petugas kesehatan khususnya perawat ICU tetap bertanggung jawab terhadap pekerjaannya mereka dan berupaya untuk mencegah agar tidak terinfesksi COVID - 19. Status kesehatan mental sangatlah penting untuk menjaga kinerja perawat. Oleh karena itu, upaya pencegahan infeksi meliputi langkah- langkah (SOP) menyediakan alat perlindungan diri (APD) yang lengkap, waktu istirahat yang cukup dan tempat khusus (akomodasi perawat) untuk tinggal jauh dari anggota keluarga dapat menurunkan kecemasan yang terjadi. Selain itu, konsultasi dengan psikolog / psikiater mungkin juga dapat mengurangi kecemasan dan mengenali potensi gangguan kesehatan mental, khususnya bagi perawat yang mempunyai kondisi kecemasan berat [28]. 


\section{Prosiding Seminar Nasional Kesehatan 2021 Lembaga Penelitian dan Pengabdian Masyarakat Universitas Muhammadiyah Pekajangan Pekalongan}

Rasa cemas sebenarnya suatu ketakutan yang diciptakan oleh diri sendiri, yang ditandai dengan selalu khawatir dan takut terhadap suatu yang belum terjadi pada keadaan atau situasi yang genting dikemudian hari. Menurut H. R. Bukhari dan Muslim bila seseorang menghadapi keadaan situasi yang berbahaya ataupun menghadapi situasi krisis / genting , maka bacalah dzikir atau doa berikut : " Laa ilaaha illallaahul 'adziimulhaliim, laa ilaaha ilallaahu rabbul 'asryil adhim, laa ilaalaha iliallaahu rabussamaawaati wa rabbul ardhi wa rabbul ' arsyil kariim." Yang artinya " Tiada Tuhan yang disembah selain Allah yang Maha Besar lagi Maha Penyantun (menahan marah), tiada Tuhan melainkan Allah yang memelihara (mempunyai) yang Maha Besar, Tiada Tuhan yang disembah melainkan Allah yang memelihara segala langit danbumi yang mempunyai, yang Maha Mulia" [40, p. 194].

\section{Kesimpulan}

Dari telaah beberapa artikel yang didapatkan dapat disimpulkan bahwa hasil penelitian 3 artikel dengan usia perawat yang bekerja di ICU dengan rata-rata $37-45$ tahun. 3 artikel mayoritas responden yang bekerja di ICU berjenis kelamin perempuan sebanyak $76 \%$ dan laki- laki $24 \%$. Dan 2 artikel menunjukan perawat yang bekerja di ICU yang memiliki pengalaman kerja dengan rata-rata 6 - 16 tahun. Berdasarkan reponden yang didapatkan prevalensi kecemasan dihasilkan 45,8\%. Maka dapat disimpulkan bahwa sebagian besar perawat ICU yang bekerja di ICU mengalami kecemasan terkait pandemi COVID-19. Tingkat kecemasan perawat ICU, hasil dari penelitian didapatkan 2 artikel bermayoritas kecemasan ringan. Akan tetapi untuk kecemasan sedang, parah (tinggi) dan sangat parah juga tidak dapat diremehkan begitu saja. Dan melakukan upaya pencegahan untuk mengurangi tingkat kecemasan pada perawat ICU.

\section{Referensi}

[1] Abdultahman., Bawatong \& Wowiling. (2015). "Job Stres, Recognition, Job Performance and Intention to Stay at Work Among Jordanian Hospital Nurses". Journal of Nursing Management, 16, 227-23

[2] Awaluddin, A. (2020). "Hubungan Pendidikan Dan Lama Kerja Dengan Tingkat Kecemasan Perawat Dalam Penanganan Pasien Gawat Darurat Di Rsud Sawerigading Kota Palopo Tahun 2019." Jurnal Kesehatan Luwu Raya, 6 (2), 512.

[3] Azoulay, E., Pochard, F., Reignier, J., Argaud,L., Bruneel,F., Courbon,P., Cariou,A., Klouche,K., Labbe, V., Barbier, F., Guitton,C., Demoule,A., Kouatchet,A., Guisset,O., Jourdain, M., Papazian,L., Van Der Meersch,L., Reuter,D., Souppart, V., Resche-rigon,M., Michael Darmon, and Nancy Kentishbarnes. (2021). "Symptoms of Mental Health Disorders in Critical Care Physicians Facing the Second Study." doi: 10.1016/j.chest.2021.05.023.

[4] Bahadir-Yilmaz E, Yuksel. A. (2020). "State anxiety levels of nurses providingcare to patients with COVID-19 in Turkey."WILEYdoi:10.1111/ppc.12661. 


\section{Prosiding Seminar Nasional Kesehatan 2021 Lembaga Penelitian dan Pengabdian Masyarakat Universitas Muhammadiyah Pekajangan Pekalongan}

[5] Baradero, M. Mary, W. D \& Anastasia M. (2016). "Keperawatan Jiwa." Jakarta: EGC, hal. 98- 101.

[6] Caillet A, Charlotte C., Sanchez R, Allaouchiche B. (2020). "Psychological Impact of COVID-19 on ICU Caregivers."Anaesthesia Critical Care \&Pain Medicine. doi:10.1016/j.accpm.2020.08.006

[7] Crowea, Sarah, A. Fuchsia Howard, Brandi Vanderspank-wright, Paula Gillis, Fiona Mcleod, Caroline Penner, and Gregory Haljan. (2020). "The Effect of COVID-19 Pandemic on the Mental Health of Canadian Critical Care Nurses Providing Patient Care during the Early Phase Pandemic: A Mixed Method Study." Intensive \& Critical Care Nursing 102999. doi: 10.1016/j.iccn.2020.102999

[8] Fadli, F., Safruddin, S., Ahmad, A. S., Sumbara, S., \& Baharuddin, R. (2020). "Faktor yang Mempengaruhi Kecemasan pada Tenaga Kesehatan Dalam Upaya Pencegahan Covid-19." Jurnal Pendidikan Keperawatan Indonesia, 6(1), 57-67.

[9] Hapsari, Hamamah \& Yulia. (2020). "Strategi Riset \& Publikasi Penelitian Bahasa. Malang: UB Press, hal. 4. Haryanto, R., \& Septimar, Z. M. (2020). Faktor-Faktor yang Mempengaruhi Tingkat Kecemasan Perawat Covid-19 Selama Pandemi di Indonesia." The Indonesian Journal of Infectious Diseases, 6 (1), 9-21

[10] Haryanto, R., \& Septimar, Z. M. (2020). "Faktor-Faktor yang Mempengaruhi Tingkat Kecemasan Perawat Covid-19 Selama Pandemi di Indonesia." The Indonesian Journal of Infectious Diseases, 6 (1), 9-21

[11] Heesakkers, Hidde, Marieke Zegers, Margo M. C. Van Mol, and Mark Van Den Boogaard. (2021). "The Impact of the First COVID-19 Surge on the Mental WellBeing of ICU Nurses: A Nationwide Survey Study." Intensive \& Critical Care Nursing 103034. doi: 10.1016/j.iccn.2021.103034.

[12] Ismail, M., \&, Bambang., (2020). "Penulisan Karya Ilmiah (SKRIPSI): Suatu Pedoman." Klaten: Lakeisha, hal. 9 - 12

[13] Jayantika, I. G. A. N. (2020). "Kecemasan Matematis (Math anxiety) dilihat dari Perbedaan Gender." KMahasaraswati Seminar Nasional Pendidikan Matematika (MAHASENDIKA). IKIP PGRI Bali, 159-163

[14] KEMENKES. (2021). "Penyebaran Kasus COVID-19 Di Indonesia." Kementerian Kesehatan Republik Indonesia. Retrieved https://www.kemkes.go.id/article/view/20012900002/kesiapsiagaanmenghadapi-infeksi-Novel-oronvirus.html.

[15] Kursumovic, E. S. Lennae \& TM Cook. (2020). "Death in Healthcsre Workes Dur to COVID-19." doi: 10.1111/anae.15116.

[16] Lasalvia A, Bonetto. C., Porru S, Carta A, Tardivo S, Bovo C, Ruggeri M, Amaddeo F. (2020). "Psychological impact of COVID-19 pandemic on healthcare workers in a highly burdened area of north-east Italy." PMCID. doi:10.1017/S2045796020001158

[17] Liu, Z., Han, B., Jiang, R., Huang, Y., Ma, C., Wen, J., Zhang, T., Wang, Y., Chen, H. \& Ma, Y. (2020). "Status Kesehatan Mental dokter dan perawat selama epidemi COVID-19 di China." 


\section{Prosiding Seminar Nasional Kesehatan 2021 \\ Lembaga Penelitian dan Pengabdian Masyarakat Universitas Muhammadiyah Pekajangan Pekalongan}

[18] Lovibond, P. F., \& Lovibond, S. H. (1995). "The structure of negative emotional states: Comparison of the Depression Anxiety Stress Scales (DASS) with the Beck Depression and Anxiety Inventories." Behaviour research and therapy, 33 (3), 335-343.

[19] Manurung, N. (2016). "Terapi Reminiscence." Jakarta: Trans Info Media, hal. 717.

[20] Manser, S. S., Houck, K., Kramer, M, D., Tabas, I. A., Brown, C. V. R., \& Coopwood, B. (2018). "Do screening and a randomized brief intervention at a Level I trauma center impat acute stress reactions to prevent later development of postraumatic setress disorder." In Journal od Trauma and Acute Care Surgery . Vol 85

[21] Moktari R, Moayedi S, Golitaleb M. (2020). "COVID-19 Pandemic and Health Anxiety among Nurses of Intensive Care Unit." Mental Health Nursing. doi: 10.1111/inm. 12800

[22] Nasus, E., Tulak, G. T., \& Bangu. (2021). "Tingkat Kecemasan Petugas Kesehatan Menjalani Rapid Test Mendeteksi Dini Covid-19." 6(1), 94-102

[23] Pappa S, Ntella. V., Giannakas T, Giannakoulis VG, Papoutsi E, Katsaounou P. (2020). "Prevalence of depression, anxiety, and insomnia among healthcare workers during the COVID-19 pandemic: A systematic review and metaanalysis." Brain Behav Immun. doi:10.1016/j.bbi.2020.05.026

[24] Peng, Xiaofan, Xiangyu Meng, Li Li, Chenghuan Hu, Wei Liu, and Zhiyong Liu. 2021. "Depressive and Anxiety Symptoms of Healthcare Workers in Intensive Care Unit Under the COVID-19 Epidemic: An Online Cross-Sectional Study In." 9(March):5-10. doi: 10.3389/fpubh.2021.603273.

[25] ZA, S., Putra D.I., Sofyan S, Bimo. (2020). "Pedoman Umum Menghadapi Pandemi Covid-19." Jakarta: Tim Kerja Kementrian Dalam Negeri Untuk Dukungan Gugus Tugas COVID-19, hal. 2 - 61.

[26] Saputri, K. M. (2016). "Hubungan Jenis Kelamin Dengan Tingkat Kecemasan pada Pasien Pre Operasi di Ruang Bedah RS Baladhika Husada Jember (Doctoral dissertation, Universitas Muhammadiyah Jember."

[27] Sari, N. (2021). "Gambaran Kecemasan Perawat Dalam Pencegahan Dan Penanganan Covid-19."Skripsi. Surakarta : Fakultas Ilmu Kesehatan Universitas Muhammadiyah Surakarta

[28] Saricam, Murat. (2020). "COVID-19-Related Anxiety in Nurses Working on Front Lines in Turkey." 20-23. doi: 10.4103/nms.nms.

[29] Snaith, R. P. (2003). "The hospital anxiety and depression scale." Health and quality of life outcomes, 1(1), 1-4

[30] Spielberger, C. D. (2010). "State-Trait anxiety inventory." The Corsini encyclopedia of psychology, 1-1

[31] Subkhan, M. (2021). 'COVID-19 In General." Proceeding Umsurabaya

[32] Sutejo. (2019). "Keperawatan Jiwa. "Jakarta: Pustaka Baru Press, hal. 145- 153

[33] Tella, Marialaura Di, Agata Benfante, Lorys Castelli, and Annunziata Romeo. 2021. "Intensive \& Critical Care Nursing Anxiety, Depression, and Posttraumatic Stress in Nurses during the COVID-19 Outbreak." Intensive \& Critical Care 


\section{Prosiding Seminar Nasional Kesehatan Lembaga Penelitian dan Pengabdian Masyarakat Universitas Muhammadiyah Pekajangan Pekalongan

Nursing 64:103014. doi: 10.1016/j.iccn.2021.103014.

[34] Wang, Z., Qiang, W., Ke, H. (2020). "A Handbook of 2019-NCoV Pneumonia Control and Prevention." China: Hubei Science and Technology Press.

[35] WHO.(2021). "Coronavirus Disease (COVID-19) Pandemic" Retrieved https://www.who.int/emergencies/diseases/novel-coronavirus-2019/query.

[36] Wiersinga WJ, Rhodes. A., Cheng AC, Peacock SJ, Prescott HC. (2020). "Pathophysiology, Transmission, Diagnosis, and Treatment of Coronavirus Disease 2019 (COVID-19):AReview." JAMA. doi:10.1001/jama.2020.12839.

[37] Williamson V, Murphy. D., Greenberg N. (2020). "COVID-19 and experiences of moral injury in front-line key workers."PMCID, 317319.doi:10.1093/occmed/kqaa052

[38] Yilmazel G, Remziye C. (2020) . "Determination of Anxiety Levels and Perspectives on the Nursing Profession among Candidate Nurses with Relation to the COVID-19 Pandemic." WILEY. doi: 10.1111/ppc.12601.

[39] Yuliana, Y. (2020). "Corona virus diseases (Covid-19): Sebuah tinjauan literatur." Wellness And Healthy Magazine,vol. 2, no. 1, hal. 187-192.

[40] Zaidin, Ali. (2010). "Agama, Kesehatan \& Keperawatan." Jakarta: Trans Info Media, hal. 194 